\title{
MULTICULTURALISM TRENDS IN MODERN LITHUANIA: PROBLEMS AND PERSPECTIVES
}

\begin{abstract}
Multiculturalism has significantly progressed over the last decade in Lithuania after the country joined European Union. The authors analyze the literature and country's situation of multiculturalism and intercultural communication topics; examine the challenges posed by the phenomenon to Lithuanian society. The survey was conducted to find out the opinion of the citizens of modern multicultural environment peculiarities in the country. The research made in Lithuania on this topic is short in order to fully assess the current situation, so the authors want to find out the general multiculturalism concept and its development trends in recent time. Main respondents were the young and middle-aged residents of the city, of which more than 40 percent have higher education. The survey results reflect the respondents' attitudes towards multiculturalism, demonstrates the limits of their tolerance to foreigners, the challenges they face in communicating with each other with different cultures. Conclusions provide insights and recommendations on what measures can be used for promoting tolerance to other cultures in the Lithuanian society and achieving most effective integration of representatives of different cultures into the public life of the country.
\end{abstract}

Key words: intercultural communication, intercultural competence. multiculturalism, representatives of different cultures

\section{Introduction}

Global co-operation with the development of various nations and intercultural dialogue is one of the key factors of an open, modern society creation and the promotion of tolerance. The international dimension outlines the importance of corporate heritage to specific region, Europe or the whole world. For example, the Lithuanian capital Vilnius, has a multiethnic city face, it was shaped for ages by many religious and ethnic communities, whose contribution led to the multiethnic and multicultural city phenomenon (http://www.kpd.lt/lt/). This has

Vladimiras Grazulis, PhD, Professor in the Mykolas Romeris University, Lithuania, e-mail: vladimirasg@takas.lt

** Ilona Kojelyte, PhD student at Mykolas Romeris University, Vilniaus kolegija University of Applied sciences, Lithuania, e-mail: ilonakojelyte@gmail.com 
had a considerable significance in choosing Vilnius city for European capital of culture 2009.

Lithuania is traditionally accredited to the relatively small and quite homogenous European countries, which is characterized by a small scale immigration - according to the data of The Department of Statistics, each year over the last decade about 2000 foreigners were coming to Lithuania, while ethnic minorities living here for a long time have already been adapted for sufficient amount of time, but is it really even in a seemingly homogeneous community, there is a reason to talk about culturally integral society? (Erentaite, 2008).

The examination of multiculturalism in the broad sense, this phenomenon includes race, ethnicity, language, sexual identity, gender, age, social class, education, religion and other cultural dimensions (American Psychological Association, 2002). Studies carried out in Lithuania (Erentaité, 2008) suggest that although macrocultural contrasts related to ethnic or religious diversity, Lithuania is unparalleled to such mixed societies like the U.S. or Western European cosmopolitan urban centers, however, there is no reason to believe that the state forming community is more homogeneous by population age, social class, sexual identity or other characteristics. Lithuania is called Catholic country, while sociological studies show the differentiation of the country's societal values and norms, because a large part of the population tolerated values is more like a secular position (Žiliukaitè, 2007), and near the cultural foundation held the conjugal family model is actively practiced in other family forms (Mitrikas, 2003). Cultural diversity, especially microcultural differences and trends in Lithuania are related to the free movement of European Union influence, the previous migration of the last decade, the rapid development of information technology and the influence of Western culture developed social priorities.

Purpose of the article - analyzing scientific publications, statistical information and using the questionnaire method, discuss multiculturalism manifestation in contemporary Lithuania, ascertain residents opinion about various cultural dimensions issues, to provide survey results analysis, the basis of which highlight the main trends of multiculturalism and the resulting problems, see the tolerance of other cultural representatives the promotion opportunities and assess the process control conditions.

\section{Multiculturalism context}

The nature of human communication depends on the lifestyle, the corresponding orientation, character, taste, interest (Ebner, 1979). It is obvious that there are universal human qualities that are specific with different nationalities, but also the national or regional culture makes the huge impact to human behavior. Different nationalities, speaking different languages, see the world's picture 
differently and also have their own way to assess phenomenon and set their affairs, they tend to deal accustomed to their community of existing codes of conduct, that is why in the face of different cultures, their implemented and learnt national concepts do not meet the regulations of those who they are communicating with. And then there rises a cultural expression: the problem of values and the essential elements acceptability (Pruskus, 2004).

A very important part of the culture is a language, which can be regarded as a conscious thought. Famous Great Britain linguist Richard D. Lewis says that when the person is speaking, only the tip of the large iceberg flashes, consisting of verbal activities, not overstepping the limits of hearing. Based on the author's assumption, we can presume that what is said is only a brief summary of the human mind, born in his inner world, so even though grammatically can be evaluated as true or false, but there will always be colored by the human worldview, which is subject to strict his native language structure (Lewis, 2000).

Geert Hofstede (2001) defines culture as ,the collective programming of the mind which distinguishes the members of one group from another." That is why it is primarily the collective behavior of the system, determined by values. Cultural values help determine how an individual or a social group reacts to its environment. Hofstede proposed paradigm, which he divided into five cultural dimensions (see Table 1). Based on these dimensions, it is possible to describe and compare the different cultures.

Table 1: Cultural dimensions according to Hofstede (2001).

\begin{tabular}{|c|c|c|}
\hline Power distance & \multirow{4}{*}{ Uncertainty avoidance } & $\begin{array}{c}\text { Long term and } \\
\text { short term orientation }\end{array}$ \\
Individualism and collectivism & & Masculinity and femininity \\
\hline
\end{tabular}

According to Diana Janušauskienè (2013) the research of tolerance is a part of values research. Mostly these studies include the treatment of various social groups, which differed markedly from the dominant majority in the culture, research. In addition to various social groups, recently the research object of national minorities is becoming more frequent with their own unique cultural flavor. As society becomes increasingly diverse, the approach to a different position, appearance, or way of life is becoming extremely important indicator showing public maturity.

Tolerance and intercultural education are very closely related. For effective cultural communication the compatible level of contemporary society's cultural literacy, in other words, intercultural competence is necessary. V. Pruskus in his book "Tarpkultūrine komunikacija ir vadyba" (2012), agrees with E. D. Hirsh, who is dividing these intercultural competence levels: 
- Needed to survive in the new cultural environment;

- Enough to enter into a foreign culture;

- Providing full existence in a new culture;

- Enabling the implementation of language singularity.

Intercultural competence is traditionally analyzed with the help of conceptual models. Cross-cultural competence (IC) model is the most used model in research. According to this model intercultural competence consists of three main components: a sufficient cultural knowledge, cultural skills or skilled actions and the corresponding motivation or personal attitude (Byram, 1997). Cultural knowledge - this is a general information about cultural practices, specific information knowledge about a particular culture, and information about your own culture knowledge; intercultural differences in communication styles and managers recognition, showing flexibility in dealing with communication misunderstandings, and feeling comfortable dealing with foreign citizens or other culture people. Cultural skills include appropriate and effective behavior, which is perceived as competent in the context of cultural diversity. This component includes such important skills as the ability to understand and clearly communicate with other cultures, decidedly conceiving communication goals, roles and norms. A personal vein describes the personal interest of cultural interaction, its emotional and physiological reaction and the degree of empathy in relation to other cultures. Is he tolerant of ambiguity and uncertainty because of cultural differences? Can he work with people of other culture (Matveev and Milter, 1995)?

Cultural identity - it is different values and different ways of dealing with things. Cultural interface success is inevitably associated with tolerance to different values, cultural diversity. Tolerance grows with recognition, knowledge and skills acquisition, formatting broader-minded personal stance. Multicultural environment, cultural identity, tolerance and the need for education - are the key components of multiculturalism.

\section{Multiculturalism in Lithuania - research discussion}

In recent years, interest in intercultural communication has been supported by the EU Council decision of 2007 established European Integration Fund, whose main goal - to support the efforts of Member States with the help of different economic situation, social standing, cultural, religious, linguistic and ethnic dependence to third-country nationals to meet the conditions of residence and to facilitate their integration into European societies. Foreign authors of scientific publications emphasize intercultural communication topics (Kaluza, Golik, 2008; Korshuk, 2008; Hańderek, 2008; Williams, 2008; Chutka, 2008), 
while Lithuanian researchers are more interested in the aspects of intercultural competence definition (P. Paurienè, 2010; Pruskus 2004, 2008, 2010, etc.) and the features of communication between Lithuanian population and foreign people (Macevičiūte, 2005). In Europe, a place where the most research has been done about this question is Germany, while in Lithuania intercultural communication thing started teaching only in 2011 Vilnius University, Faculty of Communication, the development of communication specialists (Pruskus, 2012).

The prof. of University of Wroclaw (Poland), Alicja Szerlag in 2007 completed the Vilnius region research about intercultural education of 330 families dedicated to the national specifics of structure, education system, household situation in family, education function features and their dynamics, family values enshrined. The main conclusion of this author's research: family, school, local and regional activities are the main generators ${ }^{1}$ of intercultural competence development. According to the author, ,... nationality may be a factor that helps differentiate personal relationships in defined social space. Caring that, it is important to examine inter-cultural education complexly in the context of school education (Szerlag, 2007).

D. Janušauskienè commenting researches done in Lithuania about tolerance to foreigners conducts that there is no need to talk about widespread intolerance, although relations between people of different nationalities in individual cases is a problem and a review of the various different tolerance study shows that the majority of the population in both Lithuania and ethnic Lithuania is optimistic with regard to foreigners. Made in autumn 2007, special Eurobarometer survey "Intercultural dialogue in Europe" has revealed how the residents of Lithuanian assess cultural diversity: 21 percent of Lithuanian population completely agree and 55 percent agree that the country's cultural life is highly enriched by the people with different cultural roots. In Baltic barometer survey, done in 2000 data shows that 67 percent of Lithuanians believe that you should always try to understand other than your own view. Those who think this way is 61 percent of Lithuanian Russians. Also a high tolerance of children education in their parents' native language existed for a long time. Studies from 2000 show that as much as 88 percent of Lithuanians believe that all Lithuanian residents must exercise the right to receive education in their parents' language. However, about one-third of Lithuanian express one or another negative prejudices against foreigners, for example, in 1999 carried out research of political culture showed that 34 percent of Lithuanians agree with the statement that Lithuania grants too many rights to foreigners. In autumn 2003, tolerance research, done in Lithuania have documented that negative attitudes towards Jews have 20.4 percent of respondents, and even 42.7 percent have a negative attitude against Romes (Janusauskiene 2013).

The content and context of tolerance, respect for diversity and equal opportunities for education in Lithuania was exhaustively analyzed by J. Reingardé, 
N. Vasiliauskaitė and R. Erentaitė (2012) . Social tolerance measurement research in schools environment shows that both teachers and students welcome the opportunity to interact with people from other nations, infidels, representatives of the different races, also disabled friends, neighbors, colleagues, or students who are close to themselves in personal and professional environment, but both groups investigated that the most unacceptable group for them are homosexual people. The data also shows that multicultural competence of teachers is low, local perspective is dominating, there is the lack of resources for critical reflection, teachers use media (usually the Internet) as the main information source of various cultural groups. The information about social and cultural diversity and equal opportunities given by the teachers and textbooks is considered to be the most immportant information source for the students. It is observed that the least information of social and cultural diversity and equality issues students receive from the social cultural minority groups and extracurricular activities.

Given results show that education of cross-cultural competence and tolerance for „different people "is an important and improvement-needed phenomenon in society's maturity development.

\section{Multiculturalism trends in Lithuania - focus on opportunities}

Due to Lithuanian Department of Statistics population census data of the year 2012, the population of Lithuania is about 3 million people (http://dbl.stat. gov.lt), who represent 154 nationalities, among them - 83,7 percent Lithuanian, 6,6 percent Polish, 5,3 percent Russian, 1,3 percent Belarusians, 0,6 percent Ukrainian and 0,6 percent other ethnic groups (Jews, Latvians, Germans , Tatars , Roma, and others. ). Vilnius, the capital of Lithuania, with population a little more than 600 thousand people, since the beginning was formed as a multinational city and today it still maintain this position, there are 128 nationalities in this city, whereas in Kaunas 85, in Klaipeda - 77, more than 50 nationalities are in Šiauliai and Panevėžys.

Lithuanian ethnic communities enjoy broad legislative rights and freedom in native language usage, education, culture, including: they can create and maintain their own organizations, to cooperate with compatriots who live in other countries, to cherish their nation's cultural heritage, to take educational activities and dissemination of information in their native language, Lithuania was one of the first countries in Europe that signed the Convention for the Protection of National Minorities (http://www3.lrs.lt ), which expressed the European Council's and its member states concern about the risk of ethnic minority existence. The basic principles that guide the country through the creation and implementation of ethnic policies - development of democracy, prevention of exclusion, unity and the dialogue with various ethnic groups and individu- 
als. The coexistence of European Union countries are based on common reference values of Western civilization such as democracy, tolerance, individuality (Gelumbauskas, 2004). As it is seen, tolerance for multiculturalism and its development should be included in any EU state's policy and appropriate management measures should be required. Therefore one of the priority tasks of Lithuania in controlling this process - to deepen the understanding and trust also to develop continuous dialogue between Lithuanian and Lithuanian ethnic minorities, new immigrants, tourists and others.

The authors of this article in 2013 year $09-10$ months conducted a study, which was to discuss the challenges of working and communicating in a multicultural environment: whether the population of Lithuania is inherant to familiarize different cultures, are Lithuanian people able to work and communicate with other nationalities and cultures representatives in order to live in equality, despite the different culture, lifestyle or origin.

The study was performed using an anonymous survey method, the respondents were interviewed both directly and via the Internet, nearly two hundred completed questionnaires were received. Most of the respondents are Lithuanian citizenship, one of them - an Israeli citizen. In addition to Lithuanian respondents answers there were received one reply from Estonia, Great Britain and Norway. By ethnicity respondents were distributed as follows: 76,6 percent Lithuanian, 10,4 percent - Polish, 4,2 percent - Russian , 0,5 percent - Belarusian, which is close to the Lithuanian population structure (see Table 2 ), 8,3 percent respondents did not indicate their ethnicity.

Table 2. The comparison of respondents' distribusion according to nacionalities.

\begin{tabular}{|l|l|}
\hline $\begin{array}{l}\text { Distribution of Lithuanian citizens } \\
\text { according to nationalities }\end{array}$ & $\begin{array}{l}\text { Distribution of respondents } \\
\text { according to nationalities }\end{array}$ \\
\hline $\begin{array}{l}\text { 84,2 percent Lithuanian; } 6,6 \text { percent Polish; } \\
5,8 \text { percent Russian and oth. }\end{array}$ & $\begin{array}{l}\text { 76,6, percent Lithuanian; } 10,4 \text { percent Polish, } \\
4,2 \text { percent Russian and oth. }\end{array}$ \\
\hline
\end{tabular}

The majority of respondents are women (65 percent), sorting by age - 71,4 percent of all respondents are younger than 35years old, 87,5 percent of respondents live in a city, 6,2 percent - district centers and other city type settlements, 5,2 percent - villages. 40 percent of the respondents work in the public sector, 25 percent - in private sector, 26 percent of those who answered are still studying and 9 percent don't work at all. In the survey participated 10,4 percent people with doctoral degree, 43,2 percent of the respondents have a bachelor or a master academic degree, others - have completed secondary and vocational education. Bigger part of the respondents - are young and middle aged city people, from which more than 40 percent have a higher education. 
In Lithuania, like in every other country, live people with different sex, social sectors, nationalities, race. They talk in different languages, have different traditions, follow different religions, have their own values in life and so on. Respondents were asked to evaluate, how relevant are cultural differences in Lithuania, looking at race, nationality, language, religion, sex, sexual orientation and social status (Table 3.). As we can see, for more than half people questioned, mind the linguistic differences. (54,7 percent), and a good reason for that could be lack of other language skills those respondents have, the language used by a foreigner is rarely heard, and so on., that's why there's a need for further researches about this, so that we could answer more correctly about the situation. Almost every second respondent (42,6 percent) for various reasons (including the preservation of national identity) care about ethnic diversity, even though for the majority of Lithuanian citizens ethnic differences don't cause any problems. For more than a third of people answered seem to have a problem with sexual orientation in Lithuania.

Table 3: Different cultural features relevance, $\%$

\begin{tabular}{|l|c|c|c|}
\hline \multicolumn{1}{|c|}{ Cultural differences } & Important & $\begin{array}{c}\text { Nor important, } \\
\text { nor unimportant }\end{array}$ & Doesn't care \\
\hline Race & 30.0 & 30.5 & 39.5 \\
\hline Nationality & 42.6 & 30.9 & 26.6 \\
\hline Language & 54.7 & 27.9 & 17.4 \\
\hline Religion & 12.5 & 54.8 & 32.7 \\
\hline Sex & 16.5 & 34.6 & 48.9 \\
\hline Sexual orientation & 36.4 & 30.5 & 33.2 \\
\hline Social status & 33.5 & 35.1 & 31.4 \\
\hline
\end{tabular}

Absolute majority of people asked (9 from 10) admit that religious differences don't mind them, what is tied to wide range of opportunities to practice their religion freely in Lithuania as well as to develop tolerance towards other religions. Perhaps that is because, in Lithuania there aren't many people living with different races, event 70 percent of the respondents cultural differences according race is not relevant or poses indifference.

To find out the problems of intercultural communication, it is needed to know, how often Lithuanian citizens communicate with other cultures - find out about respondent intercultural experience while working with people from other cultures in an informal environment. From the survey results it is visible, that 41,3 percent of all respondents work with people from other cultures constantly, that is once per week and more. 29,1 percent have the opportunity to work with other cultures just some times, which is once or twice a year. 37,2 percent surveyed people communicate with other culture people constantly in an 
informal environment and 36,7 percent of them communicate with representatives of other cultures just sometimes. By the way, 14,3 percent of the respondents haven't had the chance to work with people from other cultures, and 2,1 percent has never in their life communicated with a person of a different culture. (Table 4.) As you can see in the chart, 2,1 percent have no experience of inter-cultural communication at all.

Table 4: Communication with other cultures in working and informal environment frequency, \%

\begin{tabular}{|l|c|c|c|c|}
\hline & $\begin{array}{c}\text { Constantly } \\
\text { (Once a week and more) }\end{array}$ & $\begin{array}{c}\text { Often } \\
\text { (Once per month) }\end{array}$ & $\begin{array}{c}\text { Sometimes } \\
\text { (1-2 times a year) }\end{array}$ & Never \\
\hline Worked together & 41.3 & 15.3 & 29.1 & 14.3 \\
\hline $\begin{array}{l}\text { Communicated } \\
\text { in an informal } \\
\text { environment }\end{array}$ & 37.2 & 23.9 & 36.7 & 2.1 \\
\hline
\end{tabular}

Respondents, that have experience in working or communicating with other cultures, were asked - what difficulties have they encountered or have not encountered during the process of intercultural communication (Table No. 5.). We see, that even 69,6 percent of the surveyed people have a history of language barrier / miscommunication problems, 54,7 percent of the respondents had a hard time while discussing about values of life, and about customs and tradition differences - 50,0 percent of the respondents. When talking about religious differences 64,4 percent of people asked, have never faced any problems, same with social status, half of the respondents $(49,2$ percent) haven't had any problems as well.

Table 5: Frequency of facing the cultural differencies, \%

\begin{tabular}{|l|c|c|c|c|}
\hline \multicolumn{1}{|c|}{ Cultural differences } & Often & Sometimes & Never & $\begin{array}{c}\text { Don't have a } \\
\text { clear opinion }\end{array}$ \\
\hline Language barriers & 15.7 & 69.6 & 13.1 & 1.6 \\
\hline $\begin{array}{l}\text { Custom and tradition } \\
\text { differences }\end{array}$ & 7.8 & 50.0 & 37.0 & 5.2 \\
\hline Different values in life & 11.1 & 54.7 & 30.0 & 4.2 \\
\hline Religion and beliefs & 4.7 & 24.1 & 64.4 & 6.8 \\
\hline Social status difference & 6.3 & 33.5 & 49.2 & 11.0 \\
\hline
\end{tabular}

Using this survey it is set out to find out - whether Lithuanian citizens have ever encountered certain intolerance: hostility, rejection or prejudice cases because of their cultural differences (Chart No. 6.). As seen in the results the 
majority (6 out of 10), have never faced intolerance manifestation, have never felt rejected or somehow stood out because of their cultural identity. But, the research showed, that average of 3,2 percent of surveyed people meet with the problems mentioned before almost every day, and more than a third of respondents have at least once been affected by this phenomenon. Data from the survey shows that majority $(42,6$ proc.) OFM Lithuanian citizens had faced some prejudice towards them.

Table 6: Frequency of intolerance cases, \%

\begin{tabular}{|l|c|c|c|}
\hline & Fell it often & Has felt it & Never felt it \\
\hline Have you felt hostility towards you? & 2.2 & 35.1 & 62.7 \\
\hline Have you felt any prejudice towards you? & 3.7 & 42.6 & 53.7 \\
\hline Have you ever felt rejected or different? & 3.7 & 31.1 & 65.2 \\
\hline
\end{tabular}

People, who have faced intolerance in Lithuania, were questioned, if it had any effect on their opinion about other cultures and what do they think about the need of multiculturalism education in Lithuania. Not looking back to the fact that almost every $3^{\text {rd }}$ respondent has faced intolerance it doesn't change their opinion about other cultures, but 18 percent of people who answered think, that it's important to put more attention in educating the public about multiculturalism (Table No. 7.) One gets the impression that the lack of public attention to multicultural education for, 7,3 percent of the surveyed people, is the main reason to state, that other nationality and culture people should live in Lithuania as less as possible.

Finally, this study was aimed to find out respondents limits of tolerance for the representatives of other cultures and nationalities. In measuring the social distance between different groups Bogardus'o scale (Tar, 1999) is mostly used. It consists of some level questions, illustrating the limits of tolerance: 1) would you agree that the people of other nationalities lived in your country, 2) whether you would agree that the people of other nationalities lived in your town, 3) would you agree that people of other nationalities lived in your neighborhood 4) would you agree that the people of other nationalities lived with you for some time, 5) would you agree to marry someone of other nationality. Lithuanian residents have been asking these questions when other nationalities and cultures members were divided to the European Union (EU) (see Table no. 8) and non-EU citizens (see Table no. 9). 
Table 7: The limits of Lithuanian tolerance for citizens of EU and its partners, percent.

\begin{tabular}{|l|c|c|c|c|}
\hline $\begin{array}{l}\text { Would you agree that people } \\
\text { of other nationalities lived: }\end{array}$ & Yes & No & I do not know & I do not care \\
\hline$\ldots$...n Lithuania & 83,3 & 3,6 & 2,6 & 10,4 \\
\hline$\ldots$..in your town & 81,7 & 5,2 & 3,1 & 9,9 \\
\hline$\ldots$ in your neighborhood & 72,9 & 10,4 & 6,2 & 10,4 \\
\hline$\ldots$ with you for some time & 50,0 & 26,6 & 16,7 & 6,8 \\
\hline $\begin{array}{l}\text { Would you agree to marry } \\
\text { someone of other nationality? }\end{array}$ & 40,0 & 20,5 & 27,4 & 12,1 \\
\hline
\end{tabular}

The comparison of these two tables (table 8 and table 9) shows that however Lithuanian public tolerance for citizens of the EU and its partners and for non-EU citizens and its partners are different. Comparing the answers to the first stage question of tolerance shows a agreat decrese in acceptance rate (from 83,3 per cent to 66,8 percent), the approval of the second question decreases as well from the 81,7 percent to 66,5 per cent, in the third stage step the acceptance is reduced from 72,9 per cent to 56,5 per cent, in the fourth stage of the issue - from 50,0 per cent to 38,6 percent . As it can bee seen the tolerance limits of the respondents of this research presuppose their approach to marriage with a person of another nationality and it is linked to the region of origin of the other half: EU citizens have the obvious priority over the citizens from other regions (40 and 28,3 per cent respectively).

Table 8: The limits of Lithuanian tolerance for citizens of non-EU and its partners, percent.

\begin{tabular}{|l|c|c|c|c|}
\hline $\begin{array}{l}\text { Would you agree that people } \\
\text { of other nationalities lived: }\end{array}$ & Yes & No & I do not know & I do not care \\
\hline ...in Lithuania & 66,8 & 10,9 & 10,9 & 11,4 \\
\hline$\ldots$..in your town & 66,5 & 9,8 & 11,4 & 103 \\
\hline ... in your neighborhood & 56,5 & 16,3 & 13,6 & 13,6 \\
\hline$\ldots$ with you for some time & 38,6 & 35,3 & 17,9 & 8,2 \\
\hline $\begin{array}{l}\text { Would you agree to marry } \\
\text { someone of other nationality? }\end{array}$ & 28,3 & 27,7 & 28,8 & 15,2 \\
\hline
\end{tabular}

Summarizing the results, it can be said that the most common problems in communicating with representatives of other cultures according to the respondents are language barrier / miscommunication, differences in values, customs and traditions. Talking about the tolerance of the respondents for the EU and its partners and non-EU citizens and its partners, the results are different and 
comparing these two cases, respondents express a wider tolerance limits in the $\mathrm{EU}$ and its partners citizens.

\section{Conclusions}

In various theoretical sources there is said about the importance of intercultural communication and multicultural competencies needed and the necessity of the modern globalized world of heterogeneous societies communication. This is especially true in communities such as Lithuania and other European countries that joined in the different countries economic and political union. Unfortunately, the Lithuanian experience in developing multicultural competence of the people is still relatively short. In the sphere of secondary education this area is touched episodically, but as a discipline in universities it began being taught only a few years ago. Stated theoretical approaches argue that the main multicultural competence and the ability to communicate with other cultures are knowledge, skills and personal attitude, while studies show that previously mentioned things are obtained by the sources of family, school, and activities in a multicultural environment.

According to results of a survey done by the authors of an article, respondents from Lithuania, summarizing the cultural differences in the relevance of certain points of view, the most relevant cultural differences in the country are linguistically and ethnically. It only confirms the scientists' R. Lewis described the language as a national identity attribute importance.

The most positive aspect of the survey results is that the vast majority of people interviewed never faced with any intolerance in Lithuania, but some of them have experienced a certain prejudice against them. A very small percentage of the respondents share the opinion that people from other cultures to live in the least, while most of the respondents believe that it is necessary to pay more attention to public education in multiculturalism development, even though that these problematic issues are likely to be resolved through intercultural education.

The main conclusion of an article - to continually develop positive attitudes of people in the country's cultural heritage, which would promote tolerance for cultural diversity and appreciate the different ethnic groups or different cultures' raised ideas of mutual influence in the development of society. 


\section{Literature}

- Beresniova C. (2010). When intolerance means more than prejudice: Challenges to Lithuanian education reforms for social tolerance. International Perspectives on Education and Society, Volume: 14.

- Cooper P. J., Calloway-Thomas C., Simonds Ch. J. (2007) Intercultural Communication, Pearson Education.

- Degutis M. (1999). Socialiniu tyrimy metodologija. Kaunas: Naujasis lankas.

- Erentaitė R. (2008). Kultūrinės prielaidos dirbant su socialinès atskirties grupèmis: refleksijos galimybès ir ribos. Socialinis darbas, Nr. 7 (3).

- Gelumbauskas E. Tautinés mažumos Lietuvoje. Retrieved 23.11.2013 from http://www.skrynia.lt $/$ modules.php?name $=$ News\&file $=$ article\&sid $=965$.

- Gražulis V., Jagminas J. (2008). Personalo vadybos galimybių paieška dabarties iššūkių aplinkoje. Viešoji politika ir administravimas, Nr. 24.

- Hofstede G. (2001). Culture's Consequenses. Sage Publications, Thousand Oaks, London, New Delhi.

- Janušauskienė D. (2013). Tolerancijos apraiškos Lietuvoje: vertybinės nuostatos tautinių mažumų atžvilgiu. Socialiniu mokslų studijos, 5(2), p. 421-432.

- Kantas I. (1996). Politiniai traktatai. Vilnius: Aidai, p. 55.

- Lietuvos statistikos departamentas. Retrieved 15.12.2013 from http://db1. stat.gov.lt.

- Lewis R. D. (2002). Kultūrų sandūra, Alma litera.

- Miller D. (2005). Politinés minties enciklopedija. Vilnius: Mintis, p. 576.

- Miniotaite G. (2006). The Concept of Tolerance in the Practical Philosophy of Immanuel Kant. Logos 48.

- $\quad$ Reingardè J., Vasiliauskaitė N, Erentaitè R. (2010). Tolerancija ir multikulturinis ugdymas bendrojo lavinimo mokyklose. Tolerantiško jaunimo asociacija, Lygiu galimybių kontrolieriaus tarnyba, Vilnius, Kaunas.

- Pruskus V. (2004). Multikulturiné komunikacija ir vadyba. Vilnius.

- Pruskus V. (2012) Tarpkultūrine komunikacija ir vadyba. Technika, Vilnius.

- Tautiniu mažumu apsaugos pagrindu konvencija. Retrieved 15.12.2013 from http://www3.lrs.lt/pls/inter3/oldsearch.preps2?Condition1=96635\&Condition 2=Europos_Tarybos

- Tautiniu mažumu istatymas. Retrieved 05.12.2013 from http://alkas.lt/tag/ tautiniu-mazumu-istatymas/.

- Verslo kultūrinès vertybès. (2005). Technologija, Kaunas.

- Vilnius - pasaulio paveldo miestas: žydiško paveldo vertès ir įprasminimas. Retrieved 06.12.2013 from http://www.kpd.lt/lt/unescoobjektai.

Paper received: May $15^{\text {th }}, 2014$

Approved for publication: June $1^{\text {st }}, 2014$
Rad primljen: 15. maj 2014. Odobren za štampu: 1. jun 2014. 
Prof. dr Vladimiras Grazulis,

„Mykolas Romeris“ univerzitet, Litvanija

Ilona Kojelyte, doktorand

„Mykolas Romeris“ univerzitet,

„Vilniaus kolegija“ univerzitet primenjenih nauka, Litvanija

\section{MULTIKULTURALIZAM KAO TREND U MODERNOJ LITVANIJI: PROBLEMI I PERSPEKTIVE}

\section{S a ž e t a k}

Multikulturalizam u Litvaniji je znatno napredovao u poslednjih deset godina, nakon što se zemlja pridružila Evropskoj uniji. Autori analiziraju književnost i situaciju multikulturalnosti u zemlji kao i interkulturalne komunikacijske teme; ispituju izazove koje predstavlja fenomen litvanskog društva. Sprovedeno je istraživanje kako bi se ustanovilo mišljenje građana u modernoj multikulturalnoj sredin. Istraživanje u Litvaniji na ovu temu nije dovoljno sprovedeno kako bi se u potpunosti procenila trenutna situacija, tako da autori žele da saznaju generalni multikulturalni koncept i tendenciju razvoja u poslednje vreme. Glavni ispitanici su mladi i srednjovečni stanovnici grada, od kojih su više od 40 posto visoko obrazovani. Rezultati ankete odražavaju stavove ispitanika u pravcu multikulturalizma, pokazuju ograničenja njihove tolerancije prema strancima kao i izazove sa kojima se suočavaju u komunikaciji sa ljudima različitih kultura. Zaključci pružaju preporuke i uvid u ono se može upotrebiti za promovisanje tolerancije prema drugim kulturama u litvanskom društvu, kao i mogućnost ostvarivanja najefikasnije integracije predstavnika različitih kultura u javnom životu zemlje.

Ključne reči: interkulturalne komunikacije, interkulturalne kompetencije, multikulturalizam, predstavnici različitih kultura. 